DOI: $\underline{10.20472 / E S .2019 .8 .2 .005 ~}$

\title{
IS EXCHANGE RATE EFFECT TRADE BALANCE IN PAKISTAN? EVIDENCE BASED ON J- CURVE
}

\author{
AAMIR KHAN, MUHAMMAD ARSHAD KHAN, ANEEL SALMAN
}

\begin{abstract}
:
This study aims to find out the relationship of how exchange rate effect the balance of trade in Pakistan over the period 1982-2016 within the context of J-curve phenomenon. We employed an Autoregressive Distributed Lag (ARDL) approach to cointegration. To investigate the short run dynamics of the study, we have estimated an error correction model. The unit root results provide a mix of $\mathrm{I}(0)$ and $\mathrm{I}(1)$ variables. The results of diagnostic tests indicate no econometric problem in the estimated model. The CUSUM and CUSUM of squared test confirms the stability of the estimated model. We summarize the estimated results as follow: first, we found an evidence of cointegration among the variables. Second, the long run results shows significant effect of REER on trade balance in Pakistan. Third, we found an evidence of J-curve in case of Pakistan.
\end{abstract}

\section{Keywords:}

Trade Balance, Real Effective Exchange Rate, J-Curve, ARDL

JEL Classification: F14, F31

\section{Authors:}

AAMIR KHAN, COMSATS University, Islamabad, Pakistan, Pakistan, Email:

aamirhaider4343@gmail.com

MUHAMMAD ARSHAD KHAN, COMSATS University, Islamabad, Pakistan, Pakistan, Email:

arshad.khan@comsats.edu.pk

ANEEL SALMAN, COMSATS University, Islamabad, Pakistan, Email: aneel.salman@comsats.edu.pk

\section{Citation:}

AAMIR KHAN, MUHAMMAD ARSHAD KHAN, ANEEL SALMAN (2019). Is Exchange Rate Effect Trade Balance in Pakistan? Evidence Based on J- Curve. International Journal of Economic Sciences, Vol. VIII(2), pp. 60-79., 10.20472/ES.2019.8.2.005 


\section{Introduction}

Exchange rate and trade balance are important macroeconomic variables in international economics, as exchange rate plays an influential role in determining the trade balance of a country, which has ultimate effect on the whole economy. Changes in exchange rate often leads to slow down the trade process which shatters the investor's confidence and hence sluggish the process of economic growth. Changes in exchange rate can sway policy decisions, effect the volume of imports and exports and hence disturb the trade balance and balance of payments. Changes in exchange rate provide opportunity of investment to local stakeholders in foreign currency to obtain high returns and thus local currency depreciates and economic growth become venerable. Empirical literature, for example (Zubair et al., 2014) "suggested that exchange rate appreciation have positive affect on imports and negative effect on exports, while devaluation has reverse effect. Instability in exchange rate plays a vital role in determining the trade competitiveness, as real devaluation makes the exports cheaper in terms of foreign currency, which increases the level of exports of a country. Hence devaluation improves the trade balance, which indicate negative relationship. Since exchange rate of Pakistan changes rapidly, therefore it is expected that fluctuations in exchange rate will considerably affects the trade balance in Pakistan". However, some other researchers like (Miles, 1979 and YuenLing et al., 2008) "argued that the impact of exchange rate on trade balance is not significant".

Exchange rate is often discussed in macroeconomics because of its influence on the economy as a whole. Instability in the exchange rate largely influences imports and exports of a country. This study is important because exchange rate and trade balance are important economic factors that determine the external sector performance of an economy. According to the elasticity approach of devaluation, currency devaluation leads to improve the balance of trade subject to the validity of the Marshall-Learner condition. As a result, current account improves, which has ultimate object of the economic growth policies. For policymakers, the exchange rate and its ultimate effect on the trade is of great importance (Demirden, Pastine 1995). The effect of the changes in exchange rate on balance of trade is significant to apprehend, because it has ultimate effect on domestic income in an open economy. Under the fixed exchange rate system it is usually expected that depreciation of currency will reduce the balance of trade deficits, because currency depreciation will lead to increase the prices of imports in terms of domestic currency and decreases the prices of exports abroad, hence exports volume is expected to increase and imports volume to decrease and hence positive effect on balance of trade. The long and short-run effect of changes in exchange rate on balance of trade can be different, because of the slow trade adjustments to the new exchange rate regimes. Most of the literature on this study is rooted in $\mathrm{J}$-curve theory and MarshallLearner condition, we will examine the issue in the context of $\mathrm{J}$-curve theory. 
According to the J-curve theory, after the currency devaluation, a country trade balance will deteriorate initially and then rises to a point higher than the starting point. Because, as a result of currency devaluation imports become more expensive in terms of domestic currency, and after some time the export's volume may start to increase because of their lower competitive prices in foreign markets. Also the volume of imports reduces, because domestic consumers may not buy the imported goods because of its higher prices. Similarly appreciation of currency will lead to an inverted J-curve. A standard theoretical explanation referred to as $\mathrm{J}$-Curve theory is; on trade balance, exchange rate changes has two theoretical effects $\mathrm{i}$ : e the volume effect and the price effect. The price effect suggest that due to devaluation of currency imports become more expensive in terms of domestic currency and exports become cheaper in the world market. However, in short run the volume of imports and exports may not change significantly. Therefore, initially the trade balance will worsen. But after that in long run, the trade volume changes in response to the devaluation of currency and hence the trade balance improves, because our exports rises due to its low competitive prices to foreign buyers and imports decreases due higher prices in term of domestic currency (Davies, 1962).

Pakistan followed export-oriented growth policy, with the intension of attaining stability in the trade balance. To achieve this objective, different exchange rate systems was implemented at different times. The objective of these policy changes was to contain trade balance and balance of payments deficits in Pakistan. Besides real effective exchange rate, domestic (foreign) income, this study utilizes money supply and tariff rate to investigate the impact of monetary and trade reform policies on the trade balance using annual data over the period 1982-2013.

\section{Literature Review}

Currency deviation and trade balance relationship has been investigated frequently in context of J-Curve and Marshal Learner conditions. Currency devaluation is sometimes considered as effective tool for a country in decreasing the trade deficit, but it is not true all the times. Normally it is observed that depreciation of currency work well for the industrialized countries. On other hand when it comes to developing countries like Pakistan who are much dependent on imports, this probability is low. Halicioglu (2008) analyses J-Curve Phenomena for Turkey with thirteen major trading partners' economies. He reported that depreciation in currency has positive impact on Turkish trade balance.

Bahmani-Oskooee et. al. (2016) investigated the J-curve between Pakistan and US at commodity level. They found an evidence of $\mathrm{J}$-curve in 17 out of 45 industries. They also found that the short run effect lasted into long run effect only in 15 industries. By using 
disaggregated data at commodity level, they identified the industries that benefit from devaluation. Bahmani-Oskooee et. al. (2017) investigated the trade balance between UK and its 19 main trading partners including Germany, USA and China using monthly data over the period 2000M1-2016M11 using both a linear and non-linear ARDL approaches. Using a linear ARDL approach, they found an effect of devaluation on trade balance with 11 trading partners that lasted into long run effect only in five case. While estimating a non-linear ARDL model, the investigators found short run asymmetric effect of devaluation on trade balance with UK's 14 trading partners which lasted into long run effect only in eight cases. Bahmani-Oskooee and Rahman (2107) investigated the asymmetric effect of exchange rate on trade balance of 11 industries that trade between Bangladesh and United States using quarterly industry level data over the period 1996Q1-2015Q4. Linear ARDL and non-linear ARDL approaches were applied to carry out the empirical investigation. They found an evidence of short run asymmetric effect in almost all 11 industries but the short run effect transformed into a long run effect in only seven industries.

Khalid (2017) examined the J-curve phenomenon between Pakistan and her selected south Asian trade partners using the annual time series data over the period 1975-2013 using ARDL approach. The author concluded that in case of Pakistan the j-curve phenomenon is rejected with its trading partners. Rose (1991) analyzed the link between the exchange rate and balance of trade in OECD $^{1}$ countries. He reported slight association between these two variables. Similarly Rose and Yallen (1989) failed to reveal any relationship between balance of payment and real exchange rate. They examined the bilateral flows of trade among OECD countries and US. Waliullah et al. (2010) reported that exchange rate positively effects the trade balance in Pakistan. They concluded that in long run Marshall Learner conditions hold in case of Pakistan.

Aftab and Khan (2008) investigated the effect of devaluation on Pakistan's bilateral trade balances with its twelve major trading partners. They applied an Autoregressive distributed lag model (ARDL) approach. They reported significant positive effect of devaluation on trade balance with Germany, Hong-Kong, Spain, Italy and Netherland. While in case of France, UK and USA exchange rate devaluation have insignificant effect on bilateral trade. Khan et al. (2014) examined long-run and short-run volatility impact on trade balance in Pakistan. They revealed that in long run volatility in exchange rate has strong significant effect on both real import and export demand functions. While in short dimension, they concluded that volatility has insignificant impact on trade, when Pakistan trades only with developing countries. Exchange rate volatility effect on Pakistan's exports to its main trade allies was empirically examined by Aurangzeb et al. (2005) over the period 1985 to 2001 . Volatility in exchange rate was measured by using the ARCH model. The results manifest the presence of equilibrium long run association between volatility in exchange rate and other variables under consideration. The exchange rate 
uncertainty effect on Pakistan's exports to the developed countries was investigated by Kumar and Dhawan (1991) for the period 1974-1985. They reported strong evidence of adverse effect of exchange rate variability of bilateral exchange rates on exports. However the variability in nominal exchange rates is significant rather than real exchange rate. The results also manifest the presence of a strong third-country effect. Caporale and Doroodian (1994), tested the exchange rate volatility effect on the value of US imports from Canada using GARCH (Generalized Autoregressive Conditional Heteroskedasticity) model. They found significant negative link between these two variables.

Aftab and Aurangzeb (2002) analyzed Pakistan's trade performance with its 10 major trade partners. They reported that Marshal Learner condition holds in case of Pakistan. Khan and Aftab (1994) findings reveal that major improvements cannot be expected in response to currency devaluation. Bahmani-Oskooee et al. (1992) reported that the effect of devaluation on trade balance is different from country to country in the short run in case of LDCs ${ }^{2}$. Though they reported that along with J-curve, N-curve, I-curve and $\mathrm{M}$ curve are also observed in trade balance patterns. Wang et al. (2012) examined the association of changes in exchange rate on balance of trade between China and her major trading allies in long as well as in short run. They concluded that appreciation in RMB do not have an impact on Chinese trade balance. Broll and Eckwert (1999) reported positive association among volatility in exchange rate and international trade. They concluded that higher volatility in currency increases foreign trade. Though more volatility in exchange rate exposes firms to high risk. Bahmani-Oskooee and Cheema (2009) reported no evidence of long run effect nor any support for $\mathrm{J}$-curve in case of Pakistan. Yuen-Ling et al. (2008) tested Marshal-Learner along with J-curve phenomenon. They study long and short run impact of exchange rate on trade balance in case of Malaysia over the period 1955-2006. The results confirms the validity of Marshal-Learner condition. Their findings were in line with findings presented by Baharumshah (2001). Moreover, VECM technique failed to reveal any proof of worsening trade balance in short run as $\mathrm{J}$ curve suggests. Overall they concluded that trade balance of Malaysia is inconsistent with J-curve theory.

Bahmani-Oskooee and Alse (1994) investigated the association among trade balance and exchange rate of nineteen developed countries along with 22 least developed countries. They used co-integration technique for analysis. They reported exchange rate and trade balance relationship in only 6 countries. For other countries, trade balance and exchange rate are found not to be associated. Indicating devaluations do not have long term impacts on trade balances. For where there was proof of co-integration, they estimated ECM and reported evidence in favor of J-curve theory. Bahmani-Oskooee and Zhang (2013) investigated the J-curve between China and UK at industry level. They reported evidence of $\mathrm{J}$-curve in only 12 industries out of 38 industries. Moreover, the long-term effect of the depreciation of currency was favorable only in 7 industries. No 
effect of currency depreciation was observed in the four largest industries that includes Clothing, Office machines, Telecommunication apparatus and motor vehicles almost making $30 \%$ of trade share.

The effect of trade liberalization on the imports and exports of developing countries that had implemented the trade liberalization policies was investigated by Santos-Paulino and Thirlwall (2004). The findings suggested that the export were stimulated by the liberalization but at the same time it resulted in a continuous raise in the import growth that lead to a deterioration in the balance of trade and payments. Bahmani-Oskooee and Wang (2008) studied the J-curve phenomenon between USA and China, using commodity level data. The data comprised of all the items traded between china and USA, totaled 88 commodities over the period of 1978 to 2002 . Findings suggest the existence of $\mathrm{J}$-curve within 22 industries and 34 companies showed a positive reaction towards depreciation of dollar.

Bahmani-Oskooee and Ratha (2007) investigated the long and short-run effect of devaluation of Swedish currency on its trade balances with seventeen major trade allies, using disaggregated data. The short and long run impact of devaluation were simultaneously captured with the help of bounds testing approach. The results revealed an impact of devaluation of Swedish Krona on its trade balance with 14 trade partners. However, only 5 cases showed the J-curve effect. E.Yaya and Lu (2012) reported that changes in exchange rate lead to a change in the trade balance of china in the short run. Rehman and Afzal (2003) investigated the empirical validity of J-curve in case of Pakistan. Furthermore, they also investigated the long-run effect of Pak Rupee devaluation on trade balance of Pakistan. An evidence of J-curve was found, and it was concluded that in long-run the effect of real devaluation of Pak Rupee on trade balance is not favorable. Marquez (1990) suggested that the direction of trade is sensitive to changes in income and prices. The J-curve phenomenon was investigated by BahmaniOskooee and Bolhasani (2008), using disaggregate annual import and export commodity data between Canada and USA. They employed data over the period 1962-2004 from 152 industries, using the bounds testing co-integration approach and ECM. In two-third industries, they observed a short run effect of Canadian dollar depreciation. However, it is transferred into long run effect in only half of the industries.

Ahmad and Yang (2004) investigated the J-curve phenomenon for china, using the cointegration test to determine the long run impact and causality tests for identifying the short run dynamics of the study. No evidence of J-curve was found, however they found little evidence of a positive long run association between exchange rate and the trade balance. Bahmani-Oskooee and Mitra (2009) investigated the J-curve between India and USA at industry level. The results shows that in short run real devaluation of rupee has an effects on balance of trade, however this effect is transferred into the long run effect in 
almost half of the industries. Muhammad and Hussain (2010) investigated the effect of Pak rupee depreciation on its trade balance. The data set include annual observations over the period 1975-2009. Findings of the study indicate positive effect of devaluation on trade balance of Pakistan. Zubair et al. (2014) examined the effect of instable exchange rate on import and exports, trade balance, reserves and GDP of Pakistan. They performed analysis on pooled data from 1952 to 2010. Results showed a momentous impact of exchange rate on GDP. Furthermore, they reported that currency devaluation have positive impact on exports and imports. Rose (1990) empirically examined the effect of exchange rate on the trade balance in several developing economies. Findings revealed that devaluation has no association with balance of trade in most of the countries. Bahmani-Oskooee (1991) investigated the association between exchange rate and trade balance in emerging economies. Results showed that for most of the countries real effective exchange rate and trade balances are co-integrated. Moreover they observed that in long run trade balance can be improved by currency devaluation in case of LDCs. Arize (1994) reported a positive long run association between exchange rate and trade balance in most of the Asian economies.

Upadhyaya and Dhakal (1997) tested the long run effect of devaluation on balance of trade in eight developing countries from Africa, Europe, Asia and Latin America, using $A R D L$ approach. The results manifested that devaluation in long run leads to improve the balance of trade only in case of Mexico. They concluded that devaluation has negative effect in long in the case of Cyprus, Morocco and Greece, while the long run effect of devaluation is neutral in the case of Singapore, Thailand, Guatemala and Colombia. Kemal (2010) examined the nature of association between exchange rate instability and imports and exports in case of Pakistan. The study yields a result that instability in exchange rate effects imports negatively and exports positively, hence help in improving the balance of trade. Bahmani-Oskooee et al. (2008) investigated the J-curve between Canada and her 20 major trading allies over the period 1973-2000. To avoid the aggregation bias disaggregate data was used. The results provide an evidence of $\mathrm{J}$-curve in 11 out of 20 countries.

Aziz (2008) found a significant positive relationship between exchange rate and trade balance of Bangladesh. The effect of devaluation on mutual trade flows among japan and its major trading allies was investigated by Bahmani-Oskooee and Goswami (2004). Applying ARDL technique on the disaggregated data, it was found that Japan exports were not sensitive to the real exchange rates when the trade flows were determined considering foreign currency. Whereas, Japan imports were found sensitive to real exchange rates. Link between volatility in exchange rate and trade balance in case of Pakistan was examined by Shahbaz et al. (2012). They found long run association among the variability in real exchange rate and trade balance. Secondly, elasticity coefficient was found to be negative but significant which implies that there will be decline 
in trade balance of Pakistan because of currency devaluation. However, the findings did not support J-curve occurrence for Pakistan.

The effect of variability in exchange rate on the growth of exports from Pakistan to its major trading partners was investigated by Mustafa and Nishat (2004) over the period 1991-2004. Sample countries were from different regional economic blocks. Results indicated that exchange rate variability had negative but significant impact in the long run as well as in the short run with the regional trading partners including Australia, NewZealand, UK and U.S where trade volume with Pakistan was stable. No association for Bangladesh and Malaysia was found among the exchange rate variability and export growth. Australian J-curve occurrence was reviewed by Bahmani-Oskooee and Pourheydarian (1991). This study considered quarterly data for the period 1971 to 1981. The study indicated that the trade balance of Australia followed the order of fluctuation as described by delayed $\mathrm{J}$-curve occurrence in the short run. In the long run an improvement in Australian trade balance was found. Shirvani and wilbratte (1997) empirically investigated the association among the trade balance of U.S and G-7 countries and the real exchange rate. Results suggested that in long run the trade balance of G-7 countries was affected by the exchange rate. Further, it was found that trade balance was improved in the long run because of currency devaluation, hence proving the MarshalLearner condition.

\section{Model}

Following Aftab and Khan (2008), we specify the trade balance as a function of domestic (foreign) real income, real effective exchange rate and tariff rate.

$$
T B_{t}=\beta_{0}+\beta_{1} \ln R E E R_{t}+\beta_{2} \ln R Y P_{t}+\beta_{3} \ln R Y F_{t}+\beta_{4} \ln T R F_{t}+\varepsilon_{t}
$$

Where trade balance $\left(T B_{t}\right)$ is defined as the current account balance as a percentage of GDP, $R E E R_{t}$ is real effective exchange rate, $Y P_{t}$ is domestic income (Pak GDP), $Y F_{t}$ is foreign income (US GDP), and $T R F_{t}$ refers to import tariff defined as the taxes on international trade. In order to examine the impact of monetary policy on trade balance, we incorporate money supply (M2) as a measure of monetary policy in the model. Now equation (1) takes the following form:

$$
T B_{t}=\beta_{0}+\beta_{1} \ln R E E R_{t}+\beta_{2} \ln Y P_{t}+\beta_{3} \ln Y F_{t}+\beta_{4} \ln T R F_{t}+\beta_{5} M 2_{t}+\varepsilon_{t}
$$

Whereas $M 2_{t}$ refers to money supply. The estimated value of $\beta_{5}$ could be either positive or negative. For instance, if an increase in money supply leads to improve the trade 
balance, the estimated value of $\beta_{5}$ would be positive, because in this case funds become available for investment and production increases as a result exports increases. But on the other hand, if increase in money supply leads to deteriorate the trade balance, the estimated value of $\beta_{5}$ would be negative.

\section{Methodology - Autoregressive Distributed Lag (ARDL) Model}

This study uses the current account balance as a percentage of GDP as a measure of trade balance, which is our dependent variable. In many empirical studies of trade balance-exchange rate relationship, current account balance is used as a measure of trade balance such as Jeffery (2006). Current account balance as a percentage of GDP is preferable because to capture the income effect also. Pak GDP is used as a measure of domestic income, US GDP is used to measure the effect of foreign income. All regressors in the model are expressed in the form of natural log to make their elasticities directly interpretable. While we are not taking log of the dependent variable because it's negative values.

To determine the long and short run link among the variables included in the study, the traditional approaches are the Johanson co-integration and Vector Error Correction Model (VECM) framework, but this approaches are appropriate for large sample size. For a small sample size an ARDL framework developed by the Pesaran et al. (2001) is more suitable. Under the ARDL approach, regressors may include lagged level values of the regressed and current and lagged values of the explanatory variables. The ARDL approach yield robust and consistent results both in long and in short run among the trade balance and other variables included in this study as indicated in equation (1).

Another advantage of ARDL framework over other approaches is that it is extremely useful in retrieving both the long run and short run dynamics of the model. It consists of estimating the following equation:

$$
\begin{aligned}
& \Delta T B_{t}=\beta_{0}+\sum_{i=1}^{n} \beta_{1 j} \Delta \operatorname{lnREER_{t-i}}+\sum_{i=1}^{n} \beta_{2 j} \Delta \ln Y P_{t-i}+\sum_{i=1}^{n} \beta_{3 j} \Delta \ln Y F_{t-i} \\
& +\sum_{i=1}^{n} \beta_{4 j} \Delta \ln T R F_{t-i}+\sum_{i=1}^{n} \beta_{5 j} \Delta \ln M 2_{t-i}+\sum_{i=1}^{n} \beta_{6 j} \Delta \ln T B_{t-i}+ \\
& +\gamma_{2} \ln R E E R_{t-1}+\gamma_{3} \ln Y P_{t-1}+\gamma_{4} \ln Y F_{t-1}+\gamma_{5} \ln T R F_{t-1} \\
& +\gamma_{6} \ln M 2_{t-1}+\varepsilon_{t}
\end{aligned}
$$

The first part of the equation with $\beta_{i}$ represent the short run dynamics of the study, whereas the ' $\gamma$ ' represent the long run parameters of the study. Equation (3) can be estimated in two steps. First, we test the null hypothesis of 'no relationship' against the alternative i.e. 


$$
\begin{aligned}
& \mathrm{H}_{0}: \gamma_{1}=\gamma_{2}=\gamma_{3}=\gamma_{4}=\gamma_{5}=\gamma_{6}=0 \quad \text { (no long run relationship) } \\
& \mathrm{H}_{1}: \gamma_{1} \neq \gamma_{2} \neq \gamma_{3} \neq \gamma_{4} \neq \gamma_{5} \neq \gamma_{6} \neq 0
\end{aligned}
$$

The appropriate statistic to test the null hypothesis is to conduct a bounds test i: e Fstatistics. Then the calculated value is matched with the critical values tabulated by Pesaran et al. (2001). We reject the null hypothesis of no long run relationship, if the computed value exceeds the upper critical value. Similarly, we do not reject the null hypothesis, if the calculated value falls below the lower tabulated value. However, the result become indecisive, if the value falls in between the two limits.

Once the long run cointegration among the variables is confirmed in the first step, then in the second step, we estimate the error correction model to retrieve the short run dynamics of the trade balance. The ECM consist of estimating the following equation:

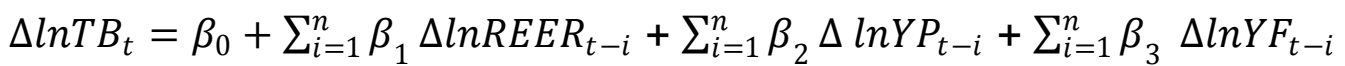

$$
\begin{aligned}
& +\sum_{i=1}^{n} \beta_{4} \Delta \operatorname{lnTRF_{t-i}}+\sum_{i=1}^{n} \beta_{5} \Delta \ln M 2_{t-i}+\sum_{i=1}^{n} \beta_{6} \Delta \ln T B_{t-i} \\
& +\lambda E C_{t-i}+v_{t}
\end{aligned}
$$

Where $\lambda$ is the speed of the adjustment parameter and $E C_{t-i}$ is the lagged error correction term.

\section{Results of Unit Root Tests}

Before examining the long run relationship, we check for time series properties of data. The standard ADF and Phillips-Perron (PP) unit root tests are used for this purpose. The results obtained from ADF and PP tests are reported in table 1 and 2 respectively. The results of ADF test indicate that at log-level, LYF and LREER are stationary at constant. At first difference, all series are stationary i. e. I(I) when we assume both constant and trend. The results of Phillip-Perron test indicate that at level only TB and LREER, LM2 and LYF are stationary at constant except LYP and LTRF which are non-stationary. At difference, all series are stationary i.e. $I(I)$, when we include both intercept and trend in the specification. So the result is a mixture of both $I(0)$ and $I(1)$ variables. Results are presented below; 
Table 1. Augmented Dicky-Fuller (ADF) Test Results

\begin{tabular}{|l|c|c|c|c|}
\hline \multirow{2}{*}{ Variables } & \multicolumn{2}{|c|}{ Level } & \multicolumn{2}{c|}{ First Difference } \\
\cline { 2 - 5 } & Constant & $\begin{array}{c}\text { Constant and } \\
\text { Trend }\end{array}$ & Constant & $\begin{array}{c}\text { Constant and } \\
\text { Trend }\end{array}$ \\
\hline TB & -2.5644 & -2.6629 & $-5.9956 * *$ & -5.9337 \\
LYP & -1.4967 & -2.1680 & $-4.1628^{* * *}$ & $-4.3994^{* * *}$ \\
LYF & $-3.2315^{* * *}$ & -1.3602 & $-4.5966^{* * *}$ & $-5.1059^{* * *}$ \\
LM2 & -1.2420 & -2.2575 & $-4.6309^{* * *}$ & $-4.5595^{* * *}$ \\
LTRF & 1.7530 & -1.7622 & $-4.0092^{* * *}$ & $-4.4178^{* * *}$ \\
LREER & $-3.3626^{* *}$ & -0.5468 & $-3.6424^{* *}$ & $-5.1894^{* * *}$ \\
\hline
\end{tabular}

Note: (1) Critical values at constant are $-3.6394,-2.9511$, and -2.6143 for $1 \%, 5 \%$, and $10 \%$ significance level.

(2) Critical values at constant and trend are $-4.2529,-3.5484$, and -3.2071 .

(3) ${ }^{*},{ }^{* *}$ and ${ }^{* * *}$ represent significance at $10 \%, 5 \%$ and $1 \%$.

Table 2. Phillips-Perron (PP) Test Results

\begin{tabular}{|l|c|c|c|c|}
\hline \multirow{2}{*}{ Variables } & \multicolumn{2}{|c|}{ Level } & \multicolumn{2}{c|}{ First Difference } \\
\cline { 2 - 5 } & Constant & $\begin{array}{c}\text { Constant and } \\
\text { Trend }\end{array}$ & Constant & Constant and Trend \\
\hline TB & -2.6999 & -2.6735 & $-5.9879^{* * *}$ & $-5.9270^{* * *}$ \\
LYP & -2.3154 & -2.1347 & $-4.1573^{* * *}$ & $-4.4211^{* * *}$ \\
LYF & $-3.0590^{* * *}$ & -1.4661 & $-4.5884^{* * *}$ & $-5.1059^{* * *}$ \\
LM2 & $17.2194^{* * *}$ & $8.3308^{* * *}$ & $-2.5653^{* * *}$ & -1.4009 \\
LTRF & 1.4294 & -1.0652 & $-4.0064^{* * *}$ & $-4.4094^{* * *}$ \\
LREER & $-3.1517^{* *}$ & -0.5335 & $-3.6332^{* *}$ & $-5.4478^{* *}$ \\
\hline
\end{tabular}

Note: (1) Critical values at constant are $-3.6394,-2.9511$, and 2.6143 for $1 \%, 5 \%$, and $10 \%$ significance level.

(2) Critical values at constant and trend are $-4.2529,-3.5485$, and -3.2071 .

(3) ${ }^{*},{ }^{* *}$ and ${ }^{* * *}$ represent significance at $10 \%, 5 \%$ and $1 \%$.

\section{Diagnostic Tests}

The estimated results passed all diagnostic tests. The results are presented in table 3 . The F-statistic for serial correlation is 0.0061 and the associated P-value is 0.9382 which is greater than the desired 5 percent significance level, hence we do not the null hypothesis of no serial correlation. The Autoregressive Conditional Heteroskedasticity $(\mathrm{ARCH})$ test for heteroscedasticity indicate no problem of heteroscedasticity, as the Fstatistics under ARCH test is 0.0425 and its P-value is 0.8379 which is insignificant, hence no ARCH effect. In other words there is no problem of heteroscedasticity. To see whether the model is correctly specified, we employed RAMSEY RESET test. The Pvalue of RAMSEY RESET test is 0.5236 , which is highly insignificant, so we do not reject 
$\mathrm{H}_{0}$ that the model is correctly specified. The Jarque-Bera test indicate that the residuals are normally distributed.

Table 3. Results of Diagnostic Tests

\begin{tabular}{lcc}
\hline Diagnostics & F-Statistics & p-value \\
\hline Serial Correlation & 0.0061 & 0.9382 \\
Heteroskedasticity & 0.0425 & 0.8379 \\
Model Specification (RAMSEY,s RESET) & 0.5236 & 0.6054 \\
Normality Test (Jarque-Bera) & 1.6660 & 0.4347 \\
\hline
\end{tabular}

Source: Own adjustment

\section{Stability tests for ARDL}

For checking the stability of the estimated model, we employed cumulative sum (CUSUM) and CUSUM squared tests, which confirms the stability of the model as manifested in figure 1 and 2 respectively.

Fig. 1. CUSUM Test for Stability of ARDL

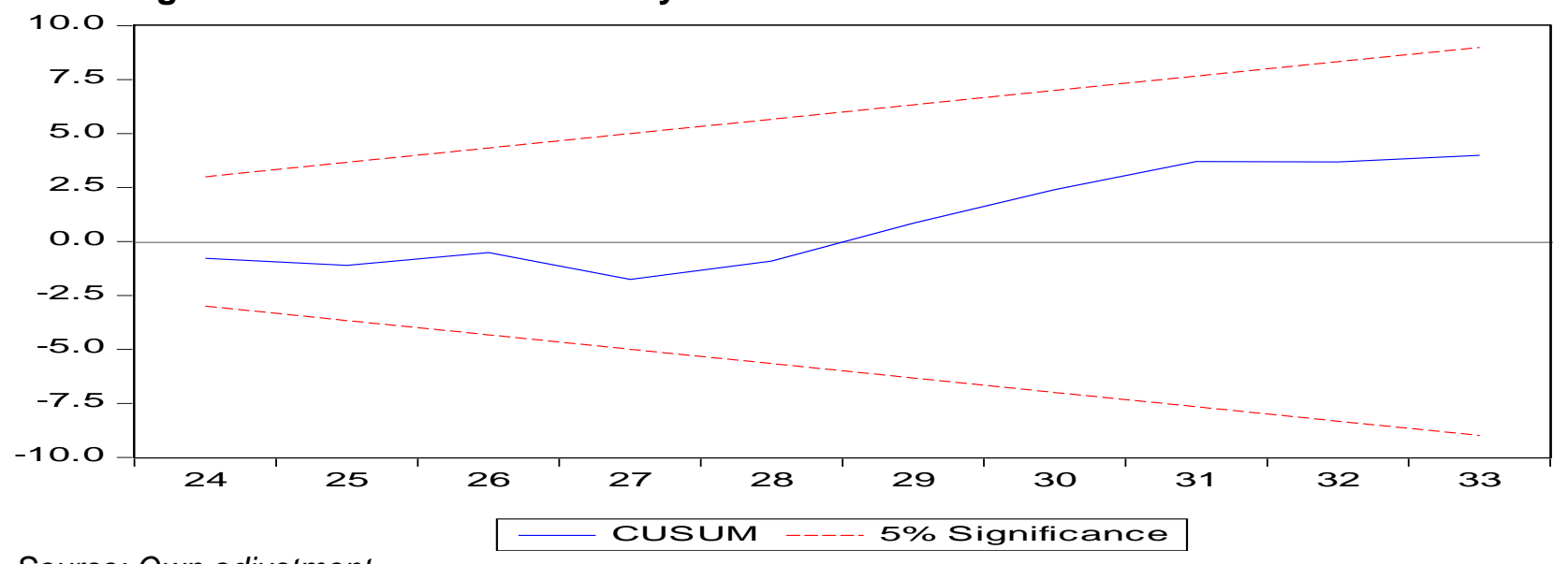

Source: Own adjustment 
Fig. 2. CUSUM of Squared Test for Stability of ARDL

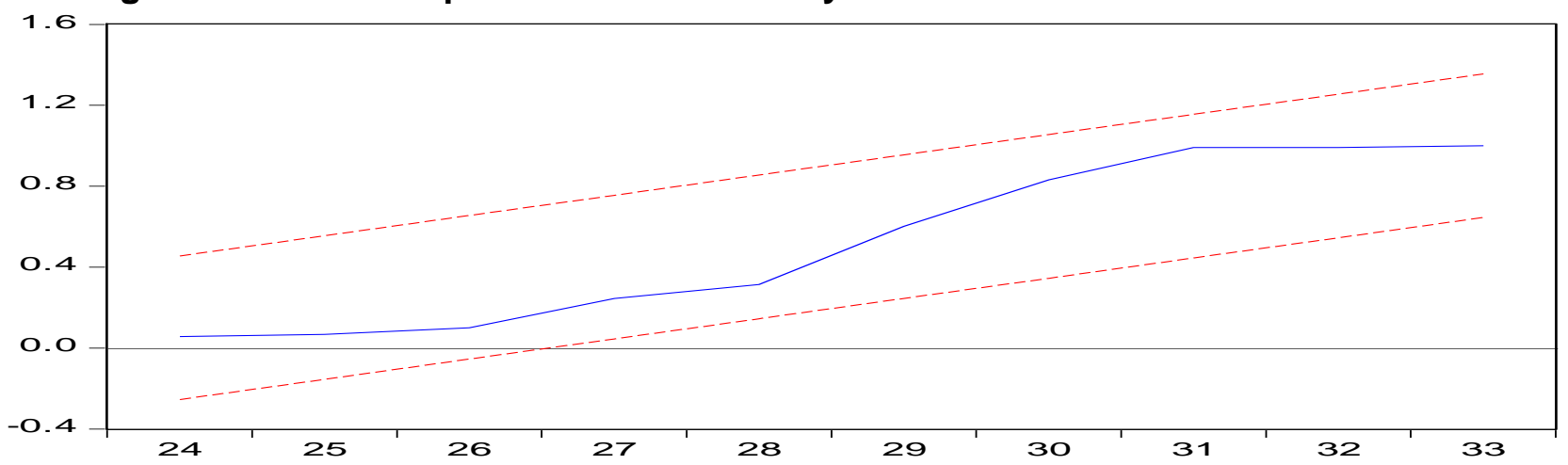

Source: Own adjustment

\section{Co-integration Test}

We employed a bound test to see whether there is a relationship among the variables. Results of the cointegration test are presented in table 5.

Table 4. Bounds Test

\begin{tabular}{lcccc}
\hline Test-Statistics & Value & Signif & $\mathrm{I}(0)$ Bound & $\mathrm{I}(1)$ Bound \\
\hline F-statistic & 5.7343 & $10 \%$ & 1.81 & 2.93 \\
K & 5 & $5 \%$ & 2.14 & 3.34 \\
& & $1 \%$ & 2.82 & 4.21 \\
\hline
\end{tabular}

From table 4, computed F-value is 5.73 , which is higher than the upper bound value at $5 \%$ significance level, which implies an evidence of cointegration among the variables i.e. the existence of long run relationship. In other words, we will reject the null hypothesis of no long run relationship against the alternative. 


\section{Long Run Results}

Long run results are presented in the below equation;

$$
\begin{array}{cccc}
T B=0.08^{* * *}(L R E E R)-0.21^{* * *}(L Y P)+0.18^{* * *}(L Y F)-0.02^{* * *}(L T R F)-0.05^{* *}(L M 2) \ldots . .(5) \\
(2.80) & (-4.33) & (5.84) & (-2.00)
\end{array}
$$

The results indicate that all variables are significant in long run. The effect of exchange rate on trade balance is positive and statistically significant, suggesting that $j$-curve holds in the long run in case of Pakistan. The result indicates that depreciation/devaluation of domestic currency by $1 \%$ leads to improve the trade balance of Pakistan by $0.08 \%$ in the long run. Sign of domestic income is negative and significant which is consistent with the economic theory. Theory indicates that increase in domestic income leads to deteriorate the trade balance, because when domestic income increases, buyers will buy more imported goods. The result indicates that $1 \%$ increase in domestic income will lead to deteriorate the trade balance of Pakistan by $0.21 \%$. Sign of foreign income (YF) is positive and statistically significant, indicating that increase in foreign income by $1 \%$ will improve the balance of trade by $0.18 \%$. The sign of foreign income is consistent with the theory. Theory indicates that when foreign income Increases, as a result foreigners will buy more imported products and hence the trade balance improves. Estimated coefficient value of tariff is negative and statistically significant. This suggests that when tariff increases by $1 \%$, it deteriorates trade balance by $0.02 \%$. The reason behind this may be that when Pakistan increases the tariff rate, as a reaction Pakistan's trade partners may also increases tariff on Pakistan exports, which ultimately constraint Pakistan's exports and reduces the market access and hence worsen the trade balance. Other implications of this result is that trade policy is also important determinant of the trade balance of Pakistan. Similarly, the sign of money supply (M2) is also negative and statistically significant, which is consistent with monetary approach to trade balance. The result indicates that in long run, $1 \%$ increase in money supply leads to deteriorate the trade balance by $0.05 \%$. Monetary policy is an effective tool of determining the trade balance. But in case of Pakistan it's not helpful in determining the trade balance in long run. 


\section{Error Correction Model (ECM)}

To examine the short run dynamics, we estimated an error correction model (ECM) as given in equation (4). The results are reported in Table 5.

Table 5. Estimated Results of ECM

\begin{tabular}{lccc}
\hline Variable & Coefficient & Std. Error & Prob. \\
\hline$\Delta$ LREER & -0.02422 & 0.0345 & 0.6602 \\
$\Delta \mathrm{LYP}$ & $-0.5798^{* * *}$ & 0.1309 & 0.0009 \\
$\Delta \mathrm{LYF}$ & $0.1266^{* * *}$ & 0.0266 & 0.0000 \\
$\Delta \mathrm{LTRF}$ & $0.1839^{* * *}$ & 0.0418 & 0.0016 \\
$\Delta \mathrm{LM} 2$ & $-0.01755^{*}$ & 0.0086 & 0.0604 \\
EC & $-0.6858^{* * *}$ & 0.0918 & 0.0000 \\
\hline R-squared & 0.8473 & S.E. of regression & 0.0129 \\
Adjusted R-squared & 0.7985 & Durbin-Watson stat & 1.9349 \\
\hline
\end{tabular}

Note: ${ }^{*},{ }^{* \star},{ }^{* * *}$ represent significance at $10 \%, 5 \%$ and $1 \%$ respectively.

Lags are selected on the basis of AIC criterion.

Source: Own adjustment

The results indicate that the error correction term has negative and statistically significant sign which approves the long run relationship among the variables. In short run, all of the variable coefficients are statistically significant, except for real effective exchange rate which is highly insignificant in the short run. The sign of domestic income is negative and statistically significant in the short run, which is consistent with economic theory. The result is aligned with the long run result. The sign of domestic income support the Keynesian view that increase in domestic income will encourage domestic buyers to buy more imported goods and thus worsen the trade balance. The effect of foreign income on balance of trade is positive and significant, which implies that Pakistan's trade balance improve by $0.12 \%$ in response to $1 \%$ increase in foreign income in the short run. This finding is consistent with economic theory i.e. when foreign income increases, as a result Pakistan's exports increases and hence trade balance improves. The estimated coefficient value of tariff is positive and statistically significant which is inconsistent with the theory i.e. the result indicate that $1 \%$ increase in tariff leads to improve the trade balance by $0.18 \%$. However, in the long run the result become consistent with the economic theory. The sign of money supply is negative and statistically significant, which is also aligned with the long run result and hence consistent with the economic theory. 


\section{Conclusions}

The major objective of this study was to explore the j-curve phenomenon in case of Pakistan and the existence of cointegration among the variables that are part of our analysis using annual time series data over the period 1982 to 2016. This study was performed using a relatively newly developed econometric approach i.e. ARDL (Autoregressive Distributed Lag) approach. To investigate the short run dynamics of the study an Error Correction Model (ECM) was developed. Since, cointegration analysis require that all variables included in the study are stationary. Therefore, before applying the cointegration test, we apply unit root tests test to check the stationarity of each variable. The tests indicate that all variables are stationary. The unit root results provide a mixture of $I(0)$ and $I(1)$ order of integration. Different diagnostic tests (autocorrelation, Heteroskedasticity, model specification and normality of residuals) are applied for the validity of the estimated model. The result of these tests were insignificant which implies no econometric problem in the estimated model. We also employed CUSUM and CUSUM of squared test which confirms the stability of the estimated model. We summarizes the empirical results as follows:

First, we found an evidence of cointegration between balance of trade, exchange rate, domestic (foreign) income, broad money and tariff rate. This implies that all the variables are moving jointly in the long run. Secondly, the long run results shows that real effective exchange rate has significant effect on the balance of trade. Hence the effect of real effective exchange rate on trade balance of Pakistan in long run is favourable. Both Domestic (foreign) income have also significant effect on trade balance of Pakistan in the long run and consistent with the theory. The sign of money supply is negative and statistically significant, which is also consistent with the monetary approach to trade balance. The long run effect of tariff rate on trade balance in Pakistan is also negative and statistically significant, which indicate that increase in tariff will negatively affect the trade balance. Third, with respect to the short run dynamics, we found no evidence of the existence of the standard $\mathrm{j}$-curve in case of Pakistan, as the coefficient of exchange rate is insignificant in the short run. In short run the signs of domestic (foreign) income is aligned with the long run results. This findings are consistent with the economic theories. The estimated short run coefficient value of tariff is negative and statistically significant and hence consistent with the underlying theories of trade policy. Money supply have negative significant sign and hence consistent with the monetary approach to trade balance. 


\section{Policy Implications}

As a policy implication this study suggest that trade balance may improve through changes in exchange rate in case of Pakistan in the long run. But not helpful as much. Therefore alternative options should be explored for the purpose of improving the trade balance. Central bank and policy makers have to stabilize the exchange rate to minimize its adverse effects on trade balance. Second, as the sign of money supply is consistent with monetary approach to trade therefore, central bank have to implement growth oriented monetary policy to achieve its positive effect. Moreover, trade policy should be accompanied by measures to enhance export competitiveness, i.e. exploring new markets rather than the current trade concentration.

\section{References}

Aftab, Z., 2002. The long-run and short-run impact of exchange rate devaluation on Pakistan's trade performance. The Pakistan Development Review, pp.277-286. https://doi.org/10.30541/v41i3pp.277286

Aftab, Z. and Khan, S., 2008. Bilateral J-curves between Pakistan and her trading partners (No. 2008: 45). Pakistan Institute of Development Economics.

Ahmad, J. and Yang, J., 2004. Estimation of the J-Curve in China.

Anju, G.K. and Uma, R., 1999. Is there a J-curve? A new estimation for Japan. International Economic Journal, 13(4), pp.71-79. https://doi.org/10.1080/10168739900000045

Arize, A.C., 1994. Cointegration test of a long-run relation between the real effective exchange rate and the trade balance. International Economic Journal, 8(3), pp.1-9. https://doi.org/10.1080/10168739400000001

Aurangzeb, A., Stengos, T. and Mohammad, A.U., 2005. Short-run and long-run effects of exchange rate volatility on the volume of exports: a case study for Pakistan. International Journal of Business and Economics, 4(3), p.209.

Aziz, N., 2008. The role of exchange rate in trade balance: Empirics from Bangladesh. University of Birmingham, UK.

Bahmani-Oskooee, M. and Alse, J., 1994. Short-run versus long-run effects of devaluation: error-correction modeling and cointegration. Eastern Economic Journal, 20(4), pp.453-464..

Bahmani-Oskooee, M. and Bolhasani, M., 2008. The J-Curve: Evidence from commodity trade between Canada and the US. Journal of Economics and finance, 32(3), pp.207-225. https://doi.org/10.1007/s12197-007-9024-0 
Bahmani-Oskooee, M. and Cheema, J., 2009. Short-run and long-run effects of currency depreciation on the bilateral trade balance between Pakistan and her major trading partners. Journal of Economic Development, 34(1), p.19. https://doi.org/10.35866/caujed.2009.34.1.002

Bahmani-Oskooee, M. and Goswami, G.G., 2004. Exchange rate sensitivity of Japan's bilateral trade flows. Japan and the world economy, 16(1), pp.1-15. https://doi.org/10.1016/S0922-1425(03)00016-1

Bahmani-Oskooee, M. and Malixi, M., 1992. More evidence on the $\mathrm{J}$ curve from LDCs. Journal of Policy Modeling, 14(5), pp.641-653. https://doi.org/10.1016/0161-8938(92)90034-A

Bahmani-Oskooee, M. and Mitra, R., 2009. The J-curve at the industry level: evidence from US-India trade. Economics Bulletin, 29(2), pp.1520-1529.

Bahmani-Oskooee, M. and Pourheydarian, M., 1991. The Australian J-curve: a reexamination. International Economic Journal, 5(3), pp.49-58. https://doi.org/10.1080/10168739100000020

Bahmani-Oskooee, M. and Rahman, M.O., 2017. The US-Bangladesh commodity trade: An asymmetry analysis. Economic Analysis and Policy. https://doi.org/10.1016/j.eap.2017.05.008

Bahmani-Oskooee, M. and Ratha, A., 2007. The bilateral J-curve: Sweden Versus her 17 Major trading partners. International Journal of Applied Economics, 4(1), pp.1-13.

Bahmani-Oskooee, M. and Wang, Y., 2008. The J-curve: evidence from commodity trade between US and China. Applied Economics, 40(21), pp.2735-2747. https://doi.org/10.1080/00036840600970328

Bahmani-Oskooee, M., 1991. Is there a long-run relation between the trade balance and the real effective exchange rate of LDCs?. Economics letters, 36(4), pp.403-407. https://doi.org/10.1016/01651765(91)90206-Z

Bahmani-Oskooee, M., Ghodsi, S.H. and Halicioglu, F., 2017. UK trade balance with its trading partners: An asymmetry analysis. Economic Analysis and Policy, 56, pp.188-199. https://doi.org/10.1016/j.eap.2017.09.005

Bahmani-Oskooee, M., lqbal, J. and Nosheen, M., 2016. Commodity trade between Pakistan and the US: is there evidence of the J-curve?. Applied Economics, 48(11), pp.957-965. https://doi.org/10.1080/00036846.2015.1090552

Bahmani-Oskooee, M. and Zhang, R., 2013. The J-Curve: Evidence from commodity trade between UK and China. Applied Economics, 45(31), pp.4369-4378. https://doi.org/10.1080/00036846.2013.783680

Bahmani-Oskooee, M., Goswami, G.G. and Talukdar, B.K., 2008. The bilateral J-curve: Canada versus her 20 trading partners. International Review of Applied Economics, 22(1), pp.93-104. https://doi.org/10.1080/02692170701745952

Broll, U. and Eckwert, B., 1999. Exchange rate volatility and international trade. Southern Economic Journal, pp.178-185. https://doi.org/10.2307/1060843

Demirden, T. and Pastine, I., 1995. Flexible exchange rates and the J-curve: An alternative approach. Economics Letters, 48(3), pp.373-377. https://doi.org/10.1016/0165-1765(94)00634-E 
Halicioglu, F., 2008. The bilateral J-curve: Turkey versus her 13 trading partners. Journal of Asian Economics, 19(3), pp.236-243. https://doi.org/10.1016/j.asieco.2008.02.006

Hussain, A. and Muhammad, S.D., 2010. The role of exchange rate on balance of trade: Empirical from Pakistan.

Kakar, M.K., Kakar, R. and Khan, W., 2010. The determinants of Pakistan's trade balance: An ARDL cointegration approach. The Lahore Journal of Economics, 15(1), p.1. https://doi.org/10.35536/lje.2010.v15.i1.a1

Kemal, M.A., 2005. Exchange rate instability and trade: The case of Pakistan (No. 2005: 186). Pakistan Institute of Development Economics.

Khalid, W., 2017. Empirical Evidence on the J-Curve Between Pakistan and Selected South Asian Trade Partners. Management, 3(4), pp.57-64. https://doi.org/10.11648/j.ebm.20170304.11

Khan, A.J., Azim, P. and Syed, S.H., 2014. The Impact of Exchange Rate Volatility on Trade.

Kumar, R. and Dhawan, R., 1991. Exchange rate volatility and Pakistan's exports to the developed world, 1974-85. World development, 19(9), pp.1225-1240. https://doi.org/10.1016/0305-750X(91)90069-T

Miles, M.A., 1979. The effects of devaluation on the trade balance and the balance of payments: some new results. Journal of Political Economy, 87(3), pp.600-620. https://doi.org/10.1086/260780

Mustafa, K., Nishat, M. and Kemal, M.A., 2004. Volatility of Exchange Rate and Export Growth in Pakistan: The Structure and Interdependence in Regional Markets [with Comments]. The Pakistan Development Review, pp.813-828. https://doi.org/10.30541/v43i4llpp.813-828

Ng, Y.L., Har, W.M. and Tan, G.M., 2008. Real exchange rate and trade balance relationship: An empirical study on Malaysia. https://doi.org/10.5539/ijbm.v3n8p130

Rehman, H.U. and Afzal, M., 2003. The J curve phenomenon: an evidence from Pakistan. Pakistan economic and social review, pp.45-58.

Rose, A.K., 1990. Exchange rates and the trade balance: some evidence from developing countries. Economics Letters, 34(3), pp.271-275. https://doi.org/10.1016/0165-1765(90)90130-S

Rose, A.K., 1991. The role of exchange rates in a popular model of international trade: Does the 'MarshallLerner' condition hold?. Journal of international economics, 30(3-4), pp.301-316. https://doi.org/10.1016/0022-1996(91)90024-Z

Rose, A.K. and Yellen, J.L., 1989. Is there a J-curve?. Journal of Monetary economics, 24(1), pp.53-68. https://doi.org/10.1016/0304-3932(89)90016-0

Santos-Paulino, A. and Thirlwall, A.P., 2004. The impact of trade liberalization on exports, imports and the balance of payments of developing countries. The Economic Journal, 114(493). https://doi.org/10.1111/j.0013-0133.2004.00187.x 
Shahbaz, M., Jalil, A. and Islam, F., 2012. Real exchange rate changes and the trade balance: The evidence from Pakistan. The International Trade Journal, 26(2), pp.139-153. https://doi.org/10.1080/08853908.2012.657588

Shirvani, H. and Wilbratte, B., 1997. The relationship between the real exchange rate and the trade balance: An empirical reassessment. International economic journal, 11(1), pp.39-50. https://doi.org/10.1080/10168739700080003

Upadhyaya, K.P. and Dhakal, D., 1997. Devaluation and the trade balance: estimating the long run effect. Applied Economics Letters, 4(6), pp.343-345. https://doi.org/10.1080/135048597355276

Wang, C.H., Lin, C.H.A. and Yang, C.H., 2012. Short-run and long-run effects of exchange rate change on trade balance: Evidence from China and its trading partners. Japan and the World Economy, 24(4), pp.266-273. https://doi.org/10.1016/j.japwor.2012.07.001

Yaya, M.E. and Lu, X., 2012. The short-run relationship between real effective exchange rate and balance of trade in China.

Zubair, M., Burney, A.I., Sarwat, S.S. and Mubin, M., 2013. Macroeconomics Relations between Exchange Rate Instability, Exchange Rate Volatility, Trade and Economic Growth Variables: The Case of Pakistan. https://doi.org/10.2139/ssrn.2534839 